\title{
ПІДВИЩЕННЯ ІМУНОЛОГІЧНОЇ ЕФЕКТИВНОСТІ ВИСОКОАКТИВНОЇ АНТИРЕТРОВІРУСНОЇ ТЕРАПІЇ У ХВОРИХ НА ВІЛ-ІНФЕКЦІЮ ЗА ДОПОМОГОЮ ЕНТЕРОСОРБЦІЇ
}

\author{
Запорізька медична академія післядипломної освіти МОЗ України
}

\begin{abstract}
Метою дослідження була оцінка впливу комбінованого застосування ВААРТ і кремнійорганічного ентеросорбенту «Атоксил» на динаміку імунологічних показників у хворих з ВІЛ-інфекцією. В дослідження було включено 39 хворих з IV клінічною стадією ВІЛінфрекції, які були рандомізовані на дві групи: перша група - 19 хворих, які отримували ВААРТ і ентеросорбент «Атоксил», друга - 20 хворих, які отримували лише ВААРТ. Середній вміст CD4-лімфоцитів склав 79 (14-270) у мкл в першій групі і 87 (51-205) у мкл в другій. у 93 \% хворих мали місце опортуністичні та СНІД-індикаторні захворювання, серед яких превалював туберкульоз (80\%). Усім хворим була призначена BAAPT за схемою AZT+3TC+EFV. Через 6 міс. лікування рівень HIV-RNA-1 в плазмі крові не визначався в $95 \%$ пацієнтів обох груп. У першій групі хворих абсолютна кількість CD4-лімфооитів за 6 міс. ВААРТ підвищилася до 201 (179-302) на мкл, і була більше $(p<0,05)$, ніж в другій групі (159 (52-198)). Таким чином, через 6 міс. ВААРТ у першій групі хворих, які додатково отримували кремнійорганічний ентеросорбент, середній приріст кількості CD4-лімфоцитів був на 70 \% вище, ніж у другій групі, яка отримувала лише ВААРТ, з однаковою вірусологічною ефрективністю противірусного лікування.
\end{abstract}

Ключові слова: ВІЛ-інфекція, ентеросорбент, BAAPT, CD4-лімфоцит, мікробна транслокація, імунна активація.

При хронічній ВІЛ-інфекції одним з важливих фракторів прогресування захворювання $€$ рівень імунної активації, яка характеризується прискореним клітинним циклом, високим рівнем апоптозу лімфоцитів, порушенням регуляції клітинного циклу і підвищеним рівнем прозапальних цитокінів. Основною ділянкою реплікації ВІЛ є лімфоїдна тканина кишечнику, тому загибель CD4-лімфоцитів на ранніх етапах ВІЛ-інфекції, апоптоз епітеліальних клітин і втрата інтегральної цілісності сли- зової оболонки призводять до аномально високого рівня мікробної транслокації без явних ознак бактеріємії, яка і $€$ однією з основних причин системної імунної активації при ВІЛ-інфекції [1-3].

Досить часто у хворих з IV клінічною стадією ВІЛінсрекції розвивається діарея, причиною якої може бути патогенна і умовно-патогенна флора, а також сам ВІЛ і лікарські препарати. Особливо часто такі прояви спостерігаються при зниженні кількості CD4-лімсоцитів менше 100 клітин в 1 мкл. Висока токсичність антиретровірусних препаратів сприяє ураженню печінки у хворих на ВІЛ-інфрекцію, особливо при наявності у них супутніх хронічних гепатитів В і C, а також ураженню нирок, що може призводити до припинення прийому ВААРТ [4].

Одним із методів зменшення мікробної транслокації і, відповідно, хронічної імунної активації при ВІЛ-інсрекції може бути використання ентеросорбентів. Детоксикаційний есрект інтенсивної ентеросорбції за 2 доби може бути зіставний з таким для одного сеансу гемосорбції, але без притаманних останній протипоказань і ускладнень [5].

Ентеросорбція характеризується простотою, безпекою і економічністю, і широко застосовується при лікуванні різних інфрекційних і неінфекційних хвороб. У хворих на ВІЛ-інфрекцію доведена ефективність ентеросорбентів у лікуванні та запобіганні розвитку інтоксикаційного та діарейного синдромів при ВААРТ, а також для корекції побічної дії антиретровірусних препаратів [5-7]. Вивчення впливу на імунологічну і вірусологічну ефрективність ВААРТ і на транслокацію кишкової мікрофрлори при ВІЛ-інфрекції не проводилося.

Метою нашого дослідження була оцінка впливу комбінованого застосування ВААРТ і кремнійорганічного ентеросорбенту «Атоксил» на динаміку імунологічних показників у хворих з ВІЛ-інфекцією.

\section{Матеріали і методи}

В дослідження було включено 39 хворих з IV клінічною стадією ВІЛ-інфекції, які були рандомізовані на дві групи: 
в першу групу увійшли 19 хворих, у яких одночасно з початком ВААРТ призначався кремнійорганічний ентеросорбент «Атоксил», у другу - 20 хворих, які отримували лише BAAPT.

Групи статистично не відрізнялися за основними клініко-лабораторними показниками (табл. 1).

В обох групах переважали чоловіки (78,9-85 \%), відсоток жінок не перевищував 15-21,6\%. Середній вік пацієнтів, як і крайні вікові значення, були близькі. В 90 \% хворих обох груп мав місце ін'єкційний шлях інфрікування. До початку BAАРТ хворі перебували на обліку в СНІД-центрі протягом
5 років. Групи не розрізнялися за статтю, середнім віком, місцем проживання, часом перебування на обліку після встановлення діагнозу «ВІЛ-інсрекція». У 93 \% хворих мали місце опортуністичні та СНІД-індикаторні захворювання, серед яких превалював туберкульоз (78-80 \%). Серед інших опортуністичних захворювань, які реєструвалися у $30 \%$ хворих, були цитомегаловірусна інсрекція, токсоплазмоз, пневмоцистоз, саркома Капоші. У 50 \% хворих обох груп реєструвалася втрата маси тіла від 5 кг до 25 кг протягом 3-6 місяців. У кожного третього хворого виявлялися довготривалі кишкові розлади.

Таблиця 1

Характеристика досліджуваних груп

\begin{tabular}{|l|c|c|}
\hline \multicolumn{1}{|c|}{ Показник } & $\begin{array}{c}\text { Перша група } \\
(\mathrm{n}=19)\end{array}$ & $\begin{array}{c}\text { Друга група } \\
(\mathrm{n}=20)\end{array}$ \\
\hline Середній вік, мін-макс & $35(27-51)$ & $33(26-40)$ \\
\hline Чоловіча стать, \% & 78,9 & 85,0 \\
\hline Час на обліку, роки & 5,2 & 5,4 \\
\hline Ін'єкційний шлях інфрікування, \% & 89,5 & 90,0 \\
\hline Наявність анемії, \% & 84,2 & 60,0 \\
\hline Хронічний гепатит В, \% & 21,1 & 15,0 \\
\hline Кількість СD4-лімфроцитів, Me (IQR) & $79(14-270)$ & $87(51-205)$ \\
\hline Вміст у плазмі НIV-RNA-1, $\lg _{10}, \mathrm{Me}(\mathrm{IQR})$ & $6(4,9-6)$ & $4,9(4,5-5,8)$ \\
\hline
\end{tabular}

Всім хворим була призначена ВААРТ за схемою AZT+3TC+EFV. У першій групі пацієнти додатково у перші два тижні прийому антиретровірусних препаратів отримували ентеросорбент «Атоксил» по 3 г перорально у вигляді водної суспензії тричі на день, за годину до вживання їжі та прийому ліків.

Рівень вірусного навантаження ВІЛ у крові визначали методом полімеразної ланцюгової реакції з використанням тест-систем Abbott Realtime ${ }^{\text {TM }}$ HIV-1 на ампліфрікаторі Abbott Real-time m2000rt (США).

Стан клітинної ланки імунної системи оцінювали шляхом визначення абсолютного і відносного чисел CD3-, CD4-, CD8-лімсоццитів та індексу імунореактивності (CD4/ CD8) за допомогою моноклональних антитіл на проточному цитофрлуориметрі COULTER ${ }^{\circledR}$ EPICS ${ }^{\circledR}$ XL (Beckmon Coulter, Франція).

Статистичну обробку отриманих даних проводили 3 використанням програмного забезпечення STATISTICA 6.1 (StatSoft, США). Нормальність розподілу ознак визначали за грасрічним методом, критерієм Ліллієсрорса і W-критерієм Шапіро-Уілка. В нашому дослідженні більшість ознак не мали нормального розподілу, тому аналіз проводився за непараметричними методами. Для описання розподілу кількісних ознак розраховували медіану (Ме) та інтерквартильний розмах (IQR). Для порівняння двох незалежних груп використовува- ли U критерій Манна-Уітні, а двох залежних груп - критерій Вілкоксона. Статистично значимою при всіх варіантах аналізу вважали різницю при р<0,05.

\section{Результати досліджень та їх обговорення}

Стартові показники клітинної ланки імунітету у хворих обох груп свідчили про тяжку імуносупресію (табл. 2).

Вміст CD4-лімфоцитів у 74,5 \% хворих був менше 200 клітин на мкл. У кожного другого хворого (51,8 \%) першої групи реєструвалися найнижчі показники CD4лімфроцитів: менше 100 мкл ${ }^{-1}$ (від 1 до 70 клітин). У таких хворих є великий ризик розвитку синдрому відновлення імунної системи, яка може спричинити смерть хворого в перші місяці проведення ВААРТ. За середніми показниками CD4-лімфоцитів та іншими показниками клітинної ланки імунітету групи не розрізнялися ( $>>0,05)$.

Рівень вірусного навантаження перед початком BAАРТ у хворих першої групи був дещо вищим ( $<<0,05)$, і склав 6 (4,9-6) lg HIV-RNA-1 у мл плазми, порівняно з 4,9 $(4,5-5,8)$ lg HIV-RNA-1 у мл плазми у другій групі. Через 6 місяців лікування рівень вірусного навантаження HIV-RNA-1 в плазмі крові не визначався в 95 \% пацієнтів обох груп, що свідчило про високу вірусологічну ефективність ВААРТ. 
Показники клітинної ланки імунітету досліджуваних груп хворих на ВІЛ-інфекцію на початку і через 6 міс. проведення ВААРТ

\begin{tabular}{|c|c|c|c|c|c|}
\hline \multirow[t]{2}{*}{ Показник } & \multicolumn{2}{|c|}{$\begin{array}{c}\text { Перша група } \\
(n=19)\end{array}$} & \multicolumn{2}{|c|}{$\begin{array}{c}\text { Друга група } \\
(n=20)\end{array}$} & \multirow[t]{2}{*}{$P$} \\
\hline & 0 міс. & 6 мiс. & 0 міс. & 6 міс. & \\
\hline CD3, \% & $\begin{array}{c}80,4 \\
(71,8-87,4)\end{array}$ & $\begin{array}{c}78,5 \\
(74,3-81,1)\end{array}$ & $\begin{array}{c}77,5 \\
(62,0-84,2)\end{array}$ & $\begin{array}{c}78,7 \\
(73,1-86,7)\end{array}$ & 0,33 \\
\hline CD3, абс. & $\begin{array}{c}958 \\
(667-1481)\end{array}$ & $\begin{array}{c}1072 \\
(647-1504)\end{array}$ & $\begin{array}{c}728 \\
(494-1286)\end{array}$ & $\begin{array}{c}932 \\
(682-1304)\end{array}$ & 0,54 \\
\hline CD4, \% & $\begin{array}{c}8,9 \\
(1,1-15,9)\end{array}$ & $\begin{array}{c}12,9 \\
(6,3-21,9)^{\star}\end{array}$ & $\begin{array}{c}6,4 \\
(3,6-15,0)\end{array}$ & $\begin{array}{c}11,4 \\
(8,4-17,0) *\end{array}$ & 0,91 \\
\hline CD4, абс. & $\begin{array}{c}79 \\
(14-270)\end{array}$ & $\begin{array}{c}201 \\
(179-302)^{\star}\end{array}$ & $\begin{array}{c}87 \\
(51-205)\end{array}$ & $\begin{array}{c}159 \\
(52-198)^{*}\end{array}$ & $<0,05$ \\
\hline CD8, \% & $\begin{array}{c}68 \\
(59-72,3)\end{array}$ & $\begin{array}{c}45 \\
(22,9-49,6)^{\star}\end{array}$ & $\begin{array}{c}61,3 \\
(44,5-71,8)\end{array}$ & $\begin{array}{c}59,8 \\
(54,5-69,5)\end{array}$ & $<0,01$ \\
\hline CD8, абс. & $\begin{array}{c}731 \\
(492-1131)\end{array}$ & $\begin{array}{c}506 \\
(196-841)^{\star}\end{array}$ & $\begin{array}{c}579 \\
(437-1128)\end{array}$ & $\begin{array}{c}674 \\
(514-957)\end{array}$ & $<0,05$ \\
\hline CD4/CD8 & $\begin{array}{c}0,15 \\
(0,01-0,26)\end{array}$ & $\begin{array}{c}0,45 \\
(0,3-0,9)^{*}\end{array}$ & $\begin{array}{c}0,15 \\
(0,01-0,25)\end{array}$ & $\begin{array}{c}0,1 \\
(0,1-0,3)\end{array}$ & $<0,01$ \\
\hline
\end{tabular}

Примітки:

1. * - значуща розбіжність з 0 міс. в окремій групі за критерієм Вілкоксона $(P<0,05)$.

2. P - рівень значущості при порівнянні показників через 6 міс. у двох групах за критерієм Манна-Уітні.

При аналізі показників клітинної ланки імунітету в обох групах було виявлено значиме підвищення абсолютної і відносної кількості CD4-лімфроцитів, що свідчило про наявність імунологічної ефективності ВААРТ (табл. 2). У той же час, в першій групі хворих з IV клінічною стадією ВІЛ-інсекції, які додатково отримували кремнійорганічний ентеросорбент, абсолютна кількість CD4-лімсоцитів за 6 місяців ВААРТ підвищилася до 201 (179-302) - середній приріст +122 мкл - $^{-1}$, і була значимо більше $(p<0,05)$, ніж в другій групі (159 (52-198)) - середній приріст +72 мкл $^{-1}$.

Крім того, в першій групі через 6 міс. ВААРТ мало місце значиме $(p<0,05)$ зниження показників абсолютної кількості CD8-лімфоцитів на 325 клітин (506-731) і відносної кількості CD8-лімфоцитів (на 23 \%). Відмічено паралельне підвищення індексу імунореактивності у 3 рази - 3 0,15 $(0,01-0,26)$ до 0,45 $(0,3-0,9)$. У другій групі динаміка показників CD8-лімфроцитів була протилежною: середня кількість їх підвищилася на 90 (579-674) клітин, і перевищила на 25 \% показники першої групи. Підвищення індексу імунореактивності протягом 6 міс. лікування у хворих не відбулося.

Таким чином, через 6 міс. ВААРТ в першій групі хворих на ВІЛ-інфекцію, які додатково отримували кремнійорганічний ентеросорбент, середній приріст кількості CD4-лімфроцитів був на 70 \% вище, ніж у другій групі, яка отримувала лише ВААРТ, відбулося зниження показників CD8-лімфроцитів на 40 \%, при підвищенні загальної кількості цих клітин в групі порівняння, з однаковою вірусологічною ефективністю противірусного лікування.

\section{Висновки}

1. Додаткове включення на початку ВААРТ у лікування хворих на ВІЛ-інфрекцію з IV клінічною стадією кремнійорганічного ентеросорбенту дозволяє підвищити рівень CD4-лімсоцитів більш як на 70 \% за 6 міс. лікування порівняно з пацієнтами, які отримують лише ВААРТ, при однаковій вірусологічній ефективності.

2. Комбінована терапія ВААРТ і кремнійорганічним ентеросорбентом сприяє зниженню активності CD8лімфоцитів і значному підвищенню значення індексу імунореактивності порівняно з монотерапією ВААРТ за 6 міс. лікування.

\section{Література}

1. Дьяченко А.Г. Блеск и нищета антиретровирусной терапии ВИЧ-инфекции / А.Г. Дьяченко, П.А. Дьяченко, Е.Н. Горобченко // Журнал клінічних та експериментальних медичних досліджень. 2013. - T. 1, № 4. - C. 372-384.

2. Determinants of anemia in postpartum HIV-negative women in Dar es Salaam, Tanzania / [P. Petraro, C. Duggan, W. Urassa et al.] // Eur. J. Clin. Nutr. - 2013. - Vol. 67, N 7. - P. 708-717.

3. Піддубна А.І. Імунологічні зміни та профріль цитокінів у хворих на ВІЛ-інфекцію / А.І. Піддубна, М.Д. Чемич // Інорекційні хвороби. - 2013. - № 2. - C. 20-26. 


\section{ОРИГІНАЛЬНІ ДОСЛІДЖЕННЯ}

4. HIV-related liver disease: ARV drugs, coinfection, and other risk factors / [M. Puoti, P. Nasta, F. Gatti et al.] // J. Int. Assoc. AIDS Care. - 2009. - Vol. 8, N 1. - P. 30-42

5. Клініко-патогенетичне обґрунтування ентеросорбційної терапії інфекційних хвороб / М.А. Андрейчин, В.Г. Ніколаєв, Я.І. Йосик, О. Ю. Бідованець // Інфекційні хвороби. - 2010. - № 4. - С. 63-69.

6. Застосування ентеросорбенту «Ентеростель» у комплексному лікуванні ВІЛ-інфрікованих хворих / [О.В. Юрченко, С.В. Федоренко, А.В. Харитонюк та ін.] // Сучасні інсрекції. - 2008. - № 1. - С. 87-93.

7. Бардахивская К.И. Поглощающие свойства энтеросорбента Энтеросгель относительно основных антиретровирусных препаратов / К.И. Бардахивская, В.Г. Николаев, Н.М. Гурина // Новости медицины и фармации. - 2010. - № 6 (312). - С. 10-11.

\section{THE IMPROVING IMMUNOLOGICAL EFFICACY OF HIGHLY ACTIVE ANTIRETROVIRAL THERAPY IN HIV-INFECTED PATIENTS BY ENTEROSORBTION}

D.H. Zhyvytsia, L.V. Zhyvytsia, V.H. Kazeka

SUMMARY. The aim of study was to evaluate the effect of combined use HAART and silicon-organic enterosorbent «Atoxil» on the dynamics of immunological parameters in patients with HIV infection. The study included 39 patients with IV clinical stage of HIV infection who were randomized into two groups: the first group 19 patients who received HAART and enterosorbent «Atoxil», the second -20 patients who received HAART alone. The average count of CD4-lymphocytes was 79 (14-270) in the first group and 87 (51-205) in the second. In $93 \%$ of patients have been opportunistic and AIDS-defining diseases, including tuberculosis prevailed (80\%). All the patients were received HAART - AZT + $3 T C+E F V$. After 6 months of treatment, the level of HIV-RNA-1 was not detected in $95 \%$ of patients in both groups. In the first group the absolute amount of CD4lymphocytes in 6 months of HAART increased to 201 $(179-302)$, and was greater $(P<0.05)$ than in the second group (159 (52-198)). Thus, after 6 months of HAART in the first group of patients who additionally received enterosorbent, the average increase in the number of CD4-lymphocyte count was $70 \%$ higher than in the second group, which received only HAART, with the same virological efficacy of antiviral treatment. Key words: HIV infection, enterosorbent, HAART, CD4 cell, microbial translocation, immune activation

Отримано 10.02.2016 p. 